\title{
Using Technology-Mediated Learning Environment to Overcome Social and Cultural Limitations in Higher Education
}

\author{
Arif Bhatti and \\ Abdallah Tubaisahat \\ Zayed University, Abu Dhabi, \\ UAE \\ arif.bhatti@zu.ac.ae \\ abdallah.tubaishat@zu.ac.ae
}

\author{
Eyas El-Qawasmeh \\ Jordan University of \\ Science \& Technology, \\ Irbid, Jordan
}

eyas@just.edu.jo

\begin{abstract}
Adoption of Internet-based communication and learning technologies could overcome the limitations caused by the social and cultural values of a society. Zayed University (ZU) is a femaleonly university in a modern Arab country that holds dear its high appreciation to cultural and social values. This paper explores the impact and effectiveness of the outcome-based technologymediated learning environment for the College of Information systems (CIS) students. This environment compliments the classroom activities. The paper concludes with some discussion on findings from a case-study of a database course. Results shows studying in this environment helped students: (a) be more confident in expressing their ideas, (b) develop their communication skills, (c) be independent learners, and (d) be more confident to do their best work.
\end{abstract}

Keywords. Learning management systems, e-learning, social and cultural issues, asynchronous learning.

\section{Introduction}

The importance of higher education to gain prosperity and to develop human resources has been realized by under-developed countries. Students in higher education require a very flexible environment to communicate and collaborate with their peers to accomplish tasks needed to succeed. In western countries where higher education is common, individuals regardless of their gender can meet, communicate and collaborate at anytime at any place of their choice. University campuses provide facilities and resources that students can use any time. In some countries and societies, it is not possible due to the cultural and social reasons.

ZU was established for national female population of United Arab Emirates. The university has five colleges and most of the faculty members are western educated to provide students learning

Material published as part of this journal, either on-line or in print, is copyrighted by Informing Science. Permission to make digital or paper copy of part or all of these works for personal or classroom use is granted without fee provided that the copies are not made or distributed for profit or commercial advantage AND that copies 1) bear this notice in full and 2) give the full citation on the first page. It is permissible to abstract these works so long as credit is given. To copy in all other cases or to republish or to post on a server or to redistribute to lists requires specific permission from the publisher at Publisher@InformingScience.org opportunities in American style of teaching ensuring a very high quality of education. ZU operations and policies reflect the impact of social and cultural values on higher education.

Advances in networking technologies and the Internet have a significant impact on teaching and learning in 
higher education (Hodges, 2004; Muhlhauser, 2002; Smith \& Winking-Diaz, 2004). ZU campuses are fully networked that allow students to connect to the university network and Internet from anywhere on campus. Each student is required to purchase a very recent laptop that she is supposed to carry with her while she is on campus. Each faculty member receives a laptop with a three-year replacement schedule. Normal working hours are 8 to 5 and students are allowed to be on campus during this period. For cultural and social reasons, students are not allowed to be oncampus after normal working hours and on weekends.

Social and cultural values of a society could impose different rules based on the gender. Females in a society are usually subject to different set of rules as compared to their male counterparts in the same society. These rules could severely limit the learning opportunities for females. In this paper, we will present a case study using hybrid teaching approach to answer how technology could overcome these limitations without violating and changing any established society rules.

In a technology-mediated learning environment, students and teachers use a wide range of Internet based tools to communicate, collaborate and share resources; these tools provide anytime anywhere learning opportunities.

In this case study, we have used the following tools in our learning environment: Blackboard, a web-based Learning Management Systems (LMS) that has discussion forum functionality and assessment tools, email and conferencing communication tools. We also used server-based computational tools such as databases, web-servers and compilers needed for CS/IS courses.

This paper discusses how educational technology could be used to enhance traditional instructorled teaching to alleviate the impact of social and cultural values on higher education to make the learning environment a place to pass information and knowledge from teacher to students, from students to teacher, and from students to students; and a place for creative thinking, and learning.

The rest of the paper is organized as follows: Section 2 discusses motivation and related work. Section 3 explains teaching and learning environment at ZU. Section 4 presents methodology and results of a case study based on a database course to show that technology-mediated environment can overcome limitations and constraints imposed by the social and cultural values. Summary and future work is presented in Section 5.

\section{Related Work}

Distance education is used to accommodate those students who could not attend regular school to learn in a traditional learning environment. Invention and adoption of Internet has a significant impact on distance education and traditional classroom based teaching.

Web-based learning (WBL) has become a major trend in teaching and learning. There are two major classes of these systems: synchronous and asynchronous (Kinshuk \& Young, 2003; Neubauer \& Lobel, 2003). Synchronous WBL systems are used to create virtual classroom environment where all students in a class are accessing same information. Computer supported collaborative work (CSCW) systems are synchronous in nature and designed to replace physical classrooms with the virtual ones (Litiu and Prakash, 2000; Marsic, 2002). Most commonly available WBL systems are asynchronous in nature. In these systems, a web server hosts course contents and other teaching material. Learners have access to this material at anytime from anywhere using suitable web-clients (Blackboard Academic Suite Instructor Manual, 2004; Linge, 2003).

Based on the mode of content delivery a learning environment could be classified in one the following three categories: (1) distance education completely online using web-based technologies, (2) traditional learning completely on-campus without web-based technologies and (3) hybrid approach where on-campus teaching is complimented with web-based teaching. Table 1 com- 
pares traditional approach of course delivering with hybrid approach. Our case study is based on hybrid approach.

In learning environments based on WBL systems, learners' self-motivation is a key ingredient to learn. Research has shown that self-efficiency is at the heart of self-motivation. Appropriate feedback to learners and good navigation experience are possible reasons to motivate learners (Hodges, 2004).

First generation asynchronous LMS provide facilities for user management and ability to publish contents. Collaboration support in these systems is limited to email and discussion forums functionality. Compared to the traditional classroom environments, e-learning systems have the following limitations: no opportunity for contextual discussions, lack of teacher's explanations and visual expressions, lack of contextual understanding (Kinshuk \& Young, 2003). Designing a good course requires the support of different perspectives on material as well as interaction features for self-directed learning and context sensitive interaction, in order to implement proper solution (Stary, 2002).

Table 1: Comparison of traditional instructor led teaching with hybrid approach

\begin{tabular}{|c|c|}
\hline Traditional Instructor-led Teaching & LMS + Instructor-led Teaching \\
\hline $\begin{array}{l}\text { Students have limited sources to learn from, } \\
\text { including teachers and some basic tools }\end{array}$ & $\begin{array}{l}\text { Students have multiple sources to learn from } \\
\text { such as teacher, LMS, and online collabora- } \\
\text { tion tools }\end{array}$ \\
\hline $\begin{array}{l}\text { The learning process is controlled by the } \\
\text { teacher }\end{array}$ & $\begin{array}{l}\text { The learning process is controlled by the } \\
\text { learner and the teacher }\end{array}$ \\
\hline $\begin{array}{l}\text { Communication can be enhanced by group ac- } \\
\text { tivities, seminar-style group discussions, etc. }\end{array}$ & $\begin{array}{l}\text { Communication is done at anytime from any- } \\
\text { where }\end{array}$ \\
\hline $\begin{array}{l}\text { Minimum or no interaction with online learn- } \\
\text { ing and communication technologies }\end{array}$ & $\begin{array}{l}\text { Almost all work is done using online learning } \\
\text { and communication technologies }\end{array}$ \\
\hline $\begin{array}{l}\text { Tracing other participants in a class is difficult } \\
\text { specially with large number of students }\end{array}$ & $\begin{array}{l}\text { Students and teacher can track other partici- } \\
\text { pants easily }\end{array}$ \\
\hline Grading is mainly done offline & Save grading time with online facilities \\
\hline Learning by teaching & Learning by doing \\
\hline Limited availability of resources & $\begin{array}{l}\text { Resources are available at anytime from any- } \\
\text { where }\end{array}$ \\
\hline
\end{tabular}

WBL systems have some advantages over traditional educational systems but there are significant limitations. These limitations could be alleviated using a hybrid environment to make web-based learning systems more attractive. Distance learning students have the following frustrations: no explanation and expression from teachers, no contextual discussion, and no regular channel to get help. A hybrid environment also removes these frustrations (Altenhofen and Schaper, 2002; Hodges, 2004; Smith \& Winking-Diaz, 2004).

In e-learning systems, the following factors contribute to effective online learning: using relevant and challenging assignments, having coordinated learning environment, adequate and timely feedback from instructors, developing rich environment for student to student interaction, flexibility in teaching and learning. In a good e-learning system, students must be able to read, criti- 
cally reflect, discuss, argue, generate and present new interpretations, share and exchange information ideas.

Traditional as well as completely online learning environments have their own limitations. A hybrid approach that combines traditional teaching with online learning could provide best of both worlds. Many universities around the world are experimenting online course-building shells, such as Blackboard and WebCT to help create learning communities. Burge (1995) argues that in a technology-mediated learning environment, instructors are asked to articulate more clearly their goals and methods to the development team members; students are asked to take more responsibility for their learning.

Principe, Eulianno, \& Lefebvre (1998) identifiy two basic levels in the utilization of computers in education: computer-based presentation, and computer-based instruction. They differ in the level of changes required in the teaching methodology. Use of multimedia presentations and web searching tools belong to the first category since they just make conventional classroom delivery more efficient and appealing; and they leave the teaching methodology largely unchanged. On the other hand, computer-based instructions imply a change in the traditional way of thinking about the discipline. It exploits the computer as added dimension to bridge the gap between the professor's knowledge and the student's ways of understanding attitude.

Our case study belongs to the later category. We have experienced the following features of developing a course in LMS, as shown in Table 2:

Table 2: LMS features

\section{LMS Features for Instructors}

More flexible use of technology time

Collaboration and communication with students

Online assessment tools and grade book

Student tracking

Authentic context for learning
LMS Features for Students
$\begin{aligned} & \text { Online materials and immediate links to in- } \\ & \text { structional resources }\end{aligned}$
Collaboration and exchange of ideas with
others for more productive work

\section{Learning Environment at Zayed University}

As a young institution, $\mathrm{ZU}$ has had the opportunity to build upon the best traditions in higher education. University is established to provide higher education to local female students. Social and cultural values in this part of the world do not allow free mixing and interaction of members of opposite genders. A strong influence of these values on students, student teacher interaction and in university policies is visible in day-to-day activities.

University policy requires students to be on-campus during the normal operating hours and students are not allowed to be on-campus after these hours. An electronic check-in and check-out system is used to ensure that students remain on-campus once they are there. Students are not al- 
lowed to leave campus without their families' permission. An attendance is required during each teaching session to ensure that students participate in class activities. During off-campus educational activities, students must be accompanied by chaperones.

ZU has a strong focus on the students' learning outcomes to improve both curriculum and learning practices. The Academic Program Model (APM) (2004) developed by faculty and staff, emphasizes on a commitment to learner-based education and to a shift in the paradigm from teaching to learning. This model focuses on what students can actually do after they graduate. More detail about this model can be found in Internal Report on Self-Assessment of ZU Based on Accreditation Standards of the Middle States Commission on Higher Education, 2004; and The Academic Program Model, 2004.

\section{Technology in Education}

ZU has an excellent technology infrastructure, and seeks to optimize the use of technology in teaching and learning. Top administration is committed to implement technology-mediated programs to achieve the outcomes outlined in the Academic Program Model.

Students have a wealth of technology available to assist them in the learning process. Actually, $\mathrm{ZU}$ is known as the laptop university in this region. For CIS students having their own laptop loaded with software used in the courses help them to complete their work independently without coming to campus during after hours. IS college has an independent network infrastructure for teaching and research, in addition to the university network. This infrastructure allows students to $\log$ into Linux servers to use tools needed for programming languages, databases and web development related courses. Students can also use Linux-based communication tools to collaborate with each other and with instructors.

Students can access their university email accounts, and Blackboard, from anywhere at anytime using a web client. Students have to be on campus to access all other computing and noncomputing resources.

Each student is required to build an electronic portfolio with details of her academic accomplishments to fulfill the graduation requirements laid out in the Academic Program Model.

Blackboard is used to post course related material. Discussion forum is used for communication among students and teacher. All course syllabi are posted online, and an effort is underway to develop course content in a multimedia format.

\section{Outcome based Model}

The purpose of the outcome based model is to provide students a focused and coherent academic program. The program is based on hybrid approach. It is outcome driven and uses the traditional Grade Point Average (GPA) system. The framework that constitutes the academic model is composed of three components (The Academic Program Model, 2004):

- Readiness program to ensure that students are competent in English language

- General Education

- Degree Majors

$\mathrm{ZU}$ has the following graduation requirements for all students regardless of their major (The Academic Program Model, 2004):

- Information Literacy and Communication

- Information Technology

- Critical Thinking and Reasoning

- Global Awareness 
- Teamwork and Leadership

CIS College has the following learning outcomes (The Academic Program Model, 2004):

- Problem Identification and Analysis

- Problem Solving

- Information Technology and Their Applications

- Systems Principles and Practices

- Technical Communication

\section{Blackboard at ZU}

Blackboard is viewed as a comprehensive and flexible e-learning software platform. It is used to enhance traditional instructor-led teaching. Blackboard allow students to create 'workspaces' to enable them to share files, messages, and URLs. Discussion forum is a collaboration tool in Blackboard that allow students and teachers to create new threads for discussion and these threads could be archived.

Blackboard allows instructors to create online course materials, communicate with their students, do online assessment, and generate course statistics. By using blackboard tools, teachers and students are involved in the learning activities in co-operative and collaborative environment.

Blackboard building blocks allow our institution to integrate external applications, tools content, and services into it (Blackboard Academic Suite Instructor Manual, 2004). Blackboard Academic Suite Release 6.1 is currently deployed at ZU. The IT department provides a comprehensive training and support for faculty who use Blackboard.

\section{Case Study}

To understand the impact of technology on students' learning, we conducted a survey. The students were asked to give their opinion on using technology-mediated learning environment and how it may overcome the social and cultural limitations.

\section{Course Setup}

The students were enrolled in an undergraduate database systems course in Fall semester of 2004/2005. All students were female. The duration of the course was 20 weeks. The course was developed using Blackboard. It is important when designing a technology-mediated course to look at as many issues as possible. Some of these issues include: student engagement, student achievement, and learning technologies.

Our intention in developing this course was to help students improve their technological capabilities, communication skills, critical thinking, and problem solving skills. We included the following items in the Blackboard for this course:

Announcements: Class announcements were posted on daily basis for in-class activities, out-ofclass activities, and reminders for the home works and project work due dates.

Assignments: Students can download files related to their home works. Students may also attach files to an assignment to submit to their instructor.

Staff and Course information: Contains contact information, course syllabus, course objectives, and learning outcomes.

Course documents: Database systems learning materials including PL/ SQL Oracle materials are posted in this section. 
External links: Web links to external course material including links to the online ZU digital library.

Communications: Blackboard discussion board is used for collaborative learning strategies including group projects, case-study discussions, and sharing of solutions to homework assignments. Students are encouraged and motivated to be engaged in active learning using discussion board by giving them credits for each post or response. Students communicate with each other and with the instructor though discussion board.

Assessment Tools: Several Blackboard tools are available to instructor including assessment tool that contains features for quizzes and surveys. Students can view grades online for immediate feedback.

\section{Methodology}

The course surveyed in this case study was offered as a mix of traditional instructor-led with extensive use of educational and communication technologies. Tools used in this class fall into the following four categories:

- Content management tools that allow instructor to present contents online. These are announcements, course information, and course documents.

- Communication and collaboration tools that allow instructor/student, and student/student communication via discussion board, and email.

- Assessment tools that allow instructor to do different kinds of online assessments (exams, quizzes, and assignments), and allow students to view their grades using the online grade book.

- Unix and Oracle tools that enable students to do their homeworks online remotely from home.

\section{Survey Results}

The survey consisted of the following six categories, including 26 questions and three commentary questions:

- Technology in CIS courses

- Communication

- Online assessment

- Course related questions

- Social aspects

- Comments

The survey is class-specific, but there are many questions that are relevant to other CIS courses that use technology-mediated learning environment.

\section{Technology in CIS courses}

According to the surveyed students, the best benefit of using Blackboard is to access online materials remotely. They felt they became more independent. $64.2 \%$ of the students indicated that taking online courses is more convenient than traditional instructor-led courses. Most of the students $(85.6 \%)$ had no problem accessing online material from home. None of the students indicated that they had problem accessing Oracle from home. $64.2 \%$ felt that using online courses allowed them to become more independent. 


\section{Communications}

$74.2 \%$ felt more comfortable in posting their opinion on discussion board than to speak up in class. The discussion board is always available and accessible by students. All students indicated they never had problems accessing the discussion board. However, most of the students were satisfied by the feedback they got from the instructor (85.6\%), most of them said they do not regularly check the discussion board until they are asked to do so $(78.5 \%)$.

Importance and potential of discussion forum tool was recognized by most of the students but did not use this tool effectively. The reason for this behavior is that students have opportunities to meet and discuss with each other while they are on campus, so they do not have motivation and need to actively participate in class discussion.

Use of technology played an important role in improving students' communications skills and confidence level. Female students are usually shy and hesitant in asking questions directly but they used email to communicate with teachers while they are on-campus or off-campus.

\section{Online Assessment}

The instructor used multiple online assessments, such as exams, quizzes, and assignments. On the other hand, students have used online grade book to check their performances in the course. All students indicated that they regularly check their online grade book. $71.4 \%$ indicated they had no problem getting online assessments to and from instructor. Students' opinion on having online exams, quizzes, class activities was equally divided. $49.5 \%$ would like an online approach while $51.5 \%$ would prefer a traditional offline approach.

\section{Course Related questions}

For CIS students, server-side technologies are very important to learn databases, networks and enterprise web applications development and deployment. Remote access via a secure Linux server allowed students to learn these technologies and collaborate with each other.

All students felt that making Oracle accessible to students from home was a strong asset to the database course. It helped them do more practice and understand course material presented in class. Also using the online learning environment (Blackboard, remote access of Oracle, and computer-based lab) made them not dependent on their teacher for help (76.1\%). Most of the students were satisfied with the online classroom environment of the database course $(85.6 \%)$.

\section{Social Aspects}

Having an online learning class, most students (71.2\%) felt they became more confident in expressing their ideas, and they were motivated to do their best work (78.5\%).

It was very interesting to learn that all students felt that usage of online learning environment removed the cultural and social limitations imposed by restrictive learning environment at ZU (opportunities to discuss with friends and to access resources after campus hours). Typical of these responses and comments are the following:

"Some students can't get together because they are living far away from each other or their families wouldn't allow them to go out by themselves. Using technology allow us to access materials from anywhere anytime"

"When students use technology they will not be limited by place (only campus) and time (during 5 days a week) to learn or study for this course. For example, on last Oracle exam even though one of the questions was difficult to answer but I used Unix to talk with other student on class. 
Also I looked for the power points on Blackboard, and searched on the internet for similar exercise"

"Sometimes we do not have the time to sit with friends after campus hours. Most of my friends live far away from our house. Using online communication overcomes this problem because most of the students can access the internet anytime"

"Some students' families do not allow their daughters to go out evening even to go to a general library. Online teaching environment helps us overcome these limitations and to do the work at home"

\section{Summary and Future Work}

Social and cultural values have different impact on female students' ability to participate in a learning process. Generally, in UAE, female students are more protected and their ability to go out and meet their peers depends on their families' permission. An effective use of technology could overcome these limitations to provide a learning environment similar to the one where there are very little or no limitations caused by the social and cultural values. Some of the important findings from the survey are: (a) Use of technology improved students' communication skills (78.6\%). They became more confident in expressing their ideas $(78.5 \%)$, (b) Using online learning environment allow students to be more independent (76.1\%), (c) Almost all students indicated in their comments that using online learning environment helped them overcome some of the cultural and social limitations imposed by existing university rules, and (d) All students felt that making Oracle accessible to students from home was a strong asset in their learning. This helped them work independently.

To understand the impact of technology on student learning in a different cultural and social environment, we have initiated a process of conducting the same survey in another university that has co-education learning environment.

\section{References}

Altenhofen, M. \& Schaper, J. (2002). Flexible instructional strategies for e-learning. In Proceedings of the 35th Annual Hawaii International Conference on System Sciences (HICSS’02).

Berge, Z. L. (1995). Facilitating computer conferencing: Recommendations from the field. Educational Technology, 35 (1), 22-30, Jan.-Feb.

Blackboard Academic Suite Instructor Manual. (2004). Blackboard Inc. URL: http://www.blackboard.com

Hodges, C. (2004). Designing to motivate: Motivational techniques to incorporate in e-learning experience. The Journal of Interactive Online Learning, 2, No. 3.

Internal Report on Self-Assessment of Zayed University Based on Accreditation Standards of the Middle States Commission on Higher Education. (2004). Zayed University.

Linge, R (2003). The good, the bad, and the ridiculous: Putting a course online with Blackboard. In The Consortium for Computing in Small Colleges.

Kinshuk, \& Young, A. (2003). Web-based asynchronous synchronous environment for online learning. Journal of the United Sates Distance Learning Association, April.

Litiu, R. \& Prakash, A. (2000). Developing adaptive groupware applications using a mobile component framework. In Proceedings of the ACM 2000 Conference on Computer Supported Cooperative Work (CSCW 2000), Philadelphia, PA.

Marsic, A. Krebs, B. Dorohonceanu, \& Tremaine, M. (2002). Designing and examining PC to palm collaboration. In Proceedings of the 35th Annual Hawaii International Conference on System Sciences (HICSS'02). 
Mazza, R. \& Dimitrova, V. (2004). Visualizing student tracking data to support instructors in web-based distance education. In Proceedings of 13th Int. Conference on World Wide Web WWW.

Muhlhauser, M. \& Trompler, C. (2002). Learning in the digital age: Paving a smooth path with digital lecture halls. Proceedings of HiCSS 35th Hawaii Intl. Conference, Waikola, HI, Jan. 7-12, 2001. pp. 352361, IEEE CS press, Los Alamitos, CA.

Neubauer, M. \& Lobel, M. (2003). The learning by doing eclassroom, Journal of the United Sates Distance Learning Association, 17 (2), 5-17.

Principe, J., Eulianno, N. \& Lefebvre, C. (1998). An interactive learning environment for adaptive systems instruction. International Conference on Acoustics, Speech, and Signal Processing, pp. 1901-1904, at Piscataway, NJ, May 1998. Retrieved Dec. 2004 from http://www.cnel.ufl.edu/files/1023120351.pdf

Smith, M.\& Winking-Diaz, A. (2004). Increasing students' interactivity in an online course. The Journal of Interactive Online Learning, 2 (3).

Stary, A. (2002). Embedding self-management and generic learning support into courseware structures. In Proceedings of the 35th Annual Hawaii International Conference on System Sciences (HICSS'02).

Zayed University, The Academic Program Model. (2004). http://www.zu.ac.ae

\section{Biographies}

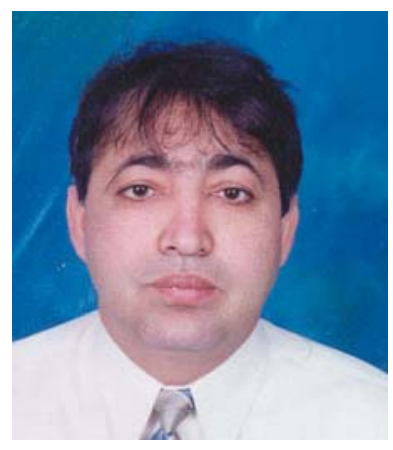

Arif Bhatti is currently an assistant professor in the College of Information Systems at Zayed University, United Arab Emirates. He received his $\mathrm{PhD}$ degree in Computer Science from the Boston University 1997 . He joined the industry as senior software engineer and worked on several projects related to the parallel computing for business and web applications for mobile users. He is interested in applied research and his research interests include parallel computing, wireless computing, and distributed online learning technologies. He is a member of the ACM.

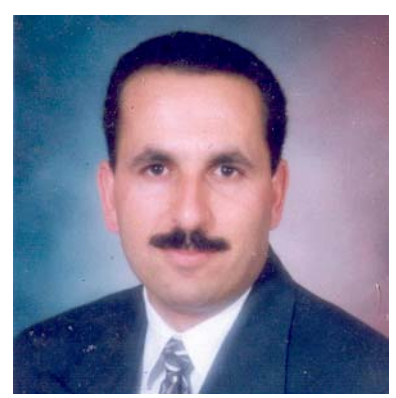

Abdallah Tubaishat is currently an assistant professor in the College of Information Systems at Zayed University, United Arab Emirates. $\mathrm{He}$ holds a PhD degree in Software Engineering from Illinois Institute of Technology, USA. Dr. Tubaishat has around 10 Years of experience in teaching and research. His research interests include e-learning, and software engineering. He has published a book with entitled "Computer Skills", and has around thirteen Journal and conference publications.

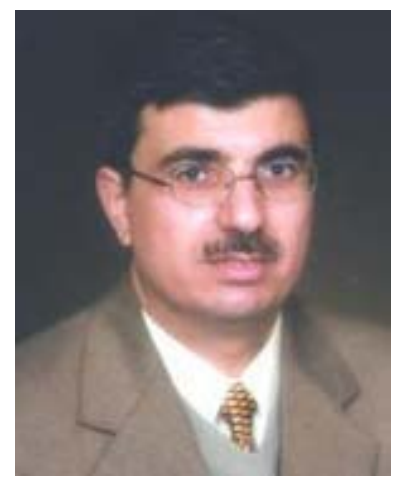

Eyas El-Qawasmeh is currently an assistant professor in the department of the Computer Science at Jordan University of Science and Technology, Jordan. He received his PhD degree in 1997 from George Washington University. In 2001, he joined George Washington University, USA as visiting researcher through a Fulbright Commission grant. In 2001, he won Hijjawi research prize for Computer Science (best computer research for 2001 in Jordan and Palestine). His areas of interest include Multimedia Databases, Information Retrieval, and Object-Oriented. He is a member of the ACM and IEEE. 